\title{
A Steam Utility Network Model for the Evaluation of Heat Integration Retrofits - A Case Study of an Oil Refinery
}

\author{
Sofie Marton', Elin Svensson ${ }^{* 2}$, Riccardo Subiaco ${ }^{3}$, Fredrik Bengtsson $^{4}$, \\ Simon Harvey \\ ${ }^{1}$ Department of Energy and Environment, Chalmers University of Technology, Maskingränd 2, \\ 41296 Göteborg, Sweden \\ e-mail: sofie.marton@chalmers.se \\ ${ }^{2}$ Department of Energy and Environment, Chalmers University of Technology, Maskingränd 2, \\ 41296 Göteborg, Sweden \\ e-mail: elin.svensson@chalmers.se \\ ${ }^{3}$ Department of Energy and Environment, Chalmers University of Technology, Maskingränd 2, \\ 41296 Göteborg, Sweden \\ e-mail: riccardo.subiaco@yahoo.com \\ ${ }^{4}$ Department of Signals and Systems, Chalmers University of Technology, Maskingränd 2, \\ 41296 Göteborg, Sweden \\ e-mail: fredben@chalmers.se \\ ${ }^{5}$ Department of Energy and Environment, Chalmers University of Technology, Maskingränd 2, \\ 41296 Göteborg, Sweden \\ e-mail: simon.harvey@chalmers.se
}

Cite as: Marton, S., Svensson, E., Subiaco, R., Bengtsson, F., Harvey, S., A Steam Utility Network Model for the Evaluation of Heat Integration Retrofits - A Case Study of an Oil Refinery, J. sustain. dev. energy water environ. syst., 5(4), pp 560-578, 2017, DOI: http://dx.doi.org/10.13044/j.sdewes.d5.0167

\begin{abstract}
This paper presents a real industrial example in which the steam utility network of a refinery is modelled in order to evaluate potential Heat Integration retrofits proposed for the site. A refinery, typically, has flexibility to optimize the operating strategy for the steam system depending on the operation of the main processes. This paper presents a few examples of Heat Integration retrofit measures from a case study of a large oil refinery. In order to evaluate expected changes in fuel and electricity imports to the refinery after implementation of the proposed retrofits, a steam system model has been developed. The steam system model has been tested and validated with steady state data from three different operating scenarios and can be used to evaluate how changes to steam balances at different pressure levels would affect overall steam balances, generation of shaft power in turbines, and the consumption of fuel gas.
\end{abstract}

\section{KEYWORDS}

Heat integration, Steam network, Energy cost savings, Oil refinery, Pinch analysis.

\section{INTRODUCTION}

Heat Integration is one important option for increasing energy efficiency in heat-intensive industrial plants such as chemical process plants and oil refineries [1]. Several approaches can be used for identifying energy efficiency options through Heat

\footnotetext{
* Corresponding author
} 
Integration [2]. The methods can generally be divided into approaches based on thermodynamics and physical insights and approaches based on mathematical programming. Methods combining these approaches have also been developed. Pinch analysis, which is based on thermodynamics and physical insights, is one of the most widely used techniques for Heat Integration.

Heat Integration in industrial processes is a difficult task since the plant layout, operability and safety issues are non-negligible and represent substantial limitations to reaching targeted minimum energy requirements. These aspects are apparent especially when dealing with retrofit of existing plants since it is usually prohibitive, practically and economically, to completely revise the plant layout for energy recovery purposes. Recent developments in methods for retrofit design of Heat Exchanger Networks (HENs) for improved Heat Integration include the Retrofit Tracing Grid Diagram [3], the Extended Grid Diagram and Shifted Retrofit Thermodynamic Grid Diagram [4], Bridge Analysis [5], and the Temperature Driving Force curves [6].

When looking at large industrial process plants, even more care must be paid when dealing with Heat Integration. In fact, Heat Integration limitations due to operability and plant layout aspects many times lead to the choice to only consider direct process-to-process integration within single process units. Because of the difficulties with direct process-to-process heat exchange across different units in a large industrial site, a heat collection and distribution system, such as steam network, is often the most practical way to deal with site wide Heat Integration and such utility systems are a central part of energy systems in refineries and petrochemical plants. However, a number of practical problems that can occur when dealing with Heat Integration in large process sites has been described in literature [7], and noted in applied studies, see e.g. [8].

Recent developments in methods for Total Site Heat Integration have been proposed to deal with some of the practical issues and to develop the existing framework and tools for retrofit purposes. For example, Liew et al. [9] proposed a tool for optimum design and planning of the utility system in a Total Site considering sensitivity to variations in operating conditions. Other examples include a Total Site Heat Integration targeting approach that incorporates plant layout considerations such as pressure drop and heat losses in the steam utility system [10] and a methodology to identify process modifications that will improve Total Site Heat Integration targets [11]. Retrofit frameworks for the Total Site have been proposed by Liew et al. [12], who implement a top-down retrofit concept that starts from the Total Site context and considers both direct and indirect heat transfer opportunities and by Gharaie et al. [13], who presented a retrofit strategy for site-wide emissions reductions that takes a holistic approach for conceptual design related to process changes, heat recovery in individual processes, efficient heat and power generation in the utility system and fuel switching. An overview of recent developments in Heat Integration retrofit of Total Sites is given in [14].

In practice, for example in applied engineering consultancy project, more established methods are typically used, and the retrofit designs are often limited to individual process units. A typical, recent example is presented by Mehdizadeh Fard et al. [15], who apply a zonal targeting approach to the retrofit of a complex natural gas refinery. To avoid difficulties related to piping distances and safety, the authors divide the Total Site into smaller areas, and apply Pinch Analysis in each area individually. In such situations, there is still a need to be able to evaluate the proposed heat recovery measures, to establish whether they will actually result in energy savings in the Total Site perspective. For example, improved heat recovery in one unit may typically lead to fuel savings in local process furnaces and a corresponding loss of steam production in process coolers. Alternatively, it may lead to steam savings in steam heaters, and a corresponding reduction of cold utility use. It is not obvious how such changes to steam balances due to retrofits within single process units affect the overall fuel and energy balances for an 
industrial plant [16]. The consequences of reduced steam demand or steam production in one unit on the site steam and fuel balances are further complicated when steam turbines are also used for steam expansion between higher and lower pressure headers, which is often the case for refinery and large petrochemical sites.

Furthermore, since process conditions constantly change with ambient conditions, raw material mixes and product demand, the steam consumption/production is not constant. In the steam system, all components are connected at the different levels and are strongly dependent on each other [17]. This means that the operation of other steam system components, like steam boilers and steam turbines, must be adjusted according to the variations in steam consumption/production caused by the process variations. In addition to variations within the industrial plants, variations in fuel and electricity prices also affect the optimal operation of the steam system components [18]. The large number of interdependencies and variations makes the system complicated and make it difficult to analyse the energy consequences of Heat Integration projects without including modelling of the steam system in the analysis. Every Heat Integration retrofit that implies a modification to the steam balances leads to a requirement for a complex decision on the best operational response for the overall steam system [19].

For example, a steam saving made at a certain pressure level leads to a choice about whether or not to turn off steam-driven turbines to be able to decrease steam production. It is therefore important to model the steam system to understand how a steam saving project would influence the fuel and electricity balances at the site, and to be able to evaluate whether it is a good HEN retrofit proposal. This importance of considering the effect on the entire steam system when making changes to a certain steam level for energy conservation projects has been demonstrated by Sun et al. [20], who also calculate a marginal cost of steam through optimisation.

During later years, models for simulation and optimization of steam utility systems have been developed to include various aspects of steam system operation such as seasonal variations [21], environmental and economical optimisation [22], availability and reliability considerations [23] and operational decisions [24]. Micheletto et al. [25] have in a case study optimized the operation of a utility system at an oil refinery for various operating conditions. Several other case studies for steam utility systems have been conducted, for example, Ruiz and Ruiz [26] write about 20 years' experience of real time optimization at various industrial sites.

As can be seen, the problem of identifying heat recovery opportunities in large process sites has been discussed in the literature from different perspectives, from process unit local integration up to site wide utility integration. However, a complex refinery or petrochemical site is seldom built upon a single complete design scheme but is often a result of several adjustments, revamps and installation of new units which therefore limits the industrial relevance of holistic design approaches. There is a need for a straight-forward approach for evaluation of suggested design changes in HENs of individual process in order to estimate the site-wide savings in fuel and changes in mechanical power production. The results are used to estimate the profitability and emissions reductions associated with the proposed measures.

The purpose of this paper is to suggest an approach that can be easily applied in engineering projects for this kind of evaluation of local Heat Integration measures from a site-wide perspective. The approach is illustrated in a case study of a complex refinery, which is currently studied in a project on operability effects of the proposed Heat Integration retrofit proposals.

The paper includes an overview of the refinery steam system at the studied oil refinery, a description of the methodology used to evaluate Heat Integration projects including a presentation of the developed steam system model, and an overview of the characteristics of the retrofit proposals that have been evaluated using the model. Finally, 
the evaluation results are presented and discussed. The focus of the results discussion is on the operational choices needed due to the steam system changes and how the energy savings for the HEN retrofits vary between three selected operating points.

\section{THE STEAM UTILITY SYSTEM}

The greatest part of the current heat demand of the case study refinery is provided by direct heating in process furnaces and by steam that is produced in steam boilers, flue-gas-heat recovery boilers and process coolers. Steam is the main utility at the refinery site. In the fractionation columns, as well as in many heat exchangers, steam is used as a heat source, and the condensate can be recovered and reused; in other units, such as strippers, it is injected to improve the process.

The steam network at the refinery, shown in Figure 1, consists of four main pressure levels: Very High Pressure (VHP), High Pressure (HP), Medium Pressure (MP) and Low Pressure (LP).

Steam at the VHP level is mainly produced in steam boilers and waste heat boilers that recover heat from flue gases from the process furnaces. The other steam headers are fed by steam generated in heat exchange with process streams.

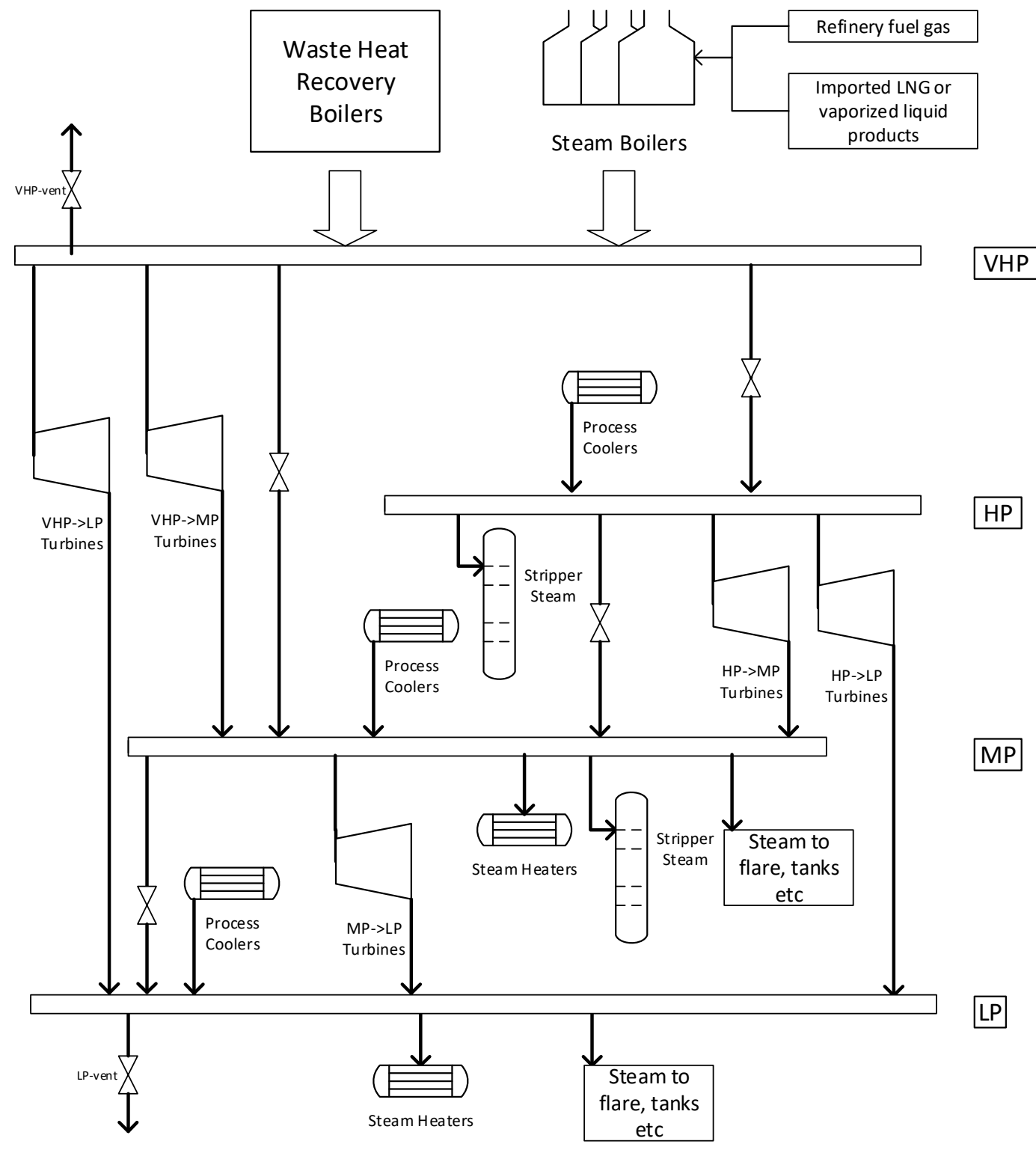

Figure 1. General overview of the refinery's steam network 
The steam boilers, like the process furnaces, are mainly fired by the so-called refinery gas that consists of the non-condensable gases from the refinery distillation columns and contains lighter petroleum products such as hydrogen, methane and ethane, but also small amounts of valuable products (such as propane and butane). Since the distillation units are equipped with an air cooling system, the amount of products that can be condensed depends, besides the crude oil formula, on the ambient air temperature. At low ambient temperatures, more valuable, liquid products can be obtained, with the result that less refinery gas is obtained. When the amount of refinery gas is not sufficient to cover the steam demand of the refinery, imported Liquefied Natural Gas (LNG) is used as make-up fuel in the steam boilers. Alternatively, liquid products such as propane and butane can be vaporized and used as a make-up fuel. On the other hand, when the outside air temperature is high, less condensable products and more refinery gas is obtained. Prolonged flaring of refinery gas is prohibited due to environmental regulations. Consequently, at times when there is an excess of refinery gas it has to be fired in the steam boilers even if the steam produced is not needed. Excess steam can be vented in limited amounts, if necessary, but to avoid a large excess of steam in such situations, the waste heat boilers can be turned off, thereby releasing hot flue gases to the atmosphere at high temperature, with a big energy loss.

The steam headers are connected by let-down valves and turbines, the latter used in direct drive configuration to operate more than fifty compressors and pumps. With the exception of the HP level, which is a local header recently built only to supply steam to the newest hydrocracker unit, the main headers are extended along the entire refinery. The flows through let-down valves between the steam headers (and to the LP vent) are automatically controlled to keep the set-point pressures of the headers. Manual operator decisions can be made to turn on or off various turbines in the network. These turbines drive pumps and compressors, that can be switched between steam turbine drive and electric motor drive (see Figure 2). There is no electrical energy production on site.

To summarize, the balances of the fuel and steam systems vary depending on the operating conditions. The typical characteristics of two distinctly different operating modes are described in Table 1 and Figure 3 shows an overview of the main energy flows within the plant.

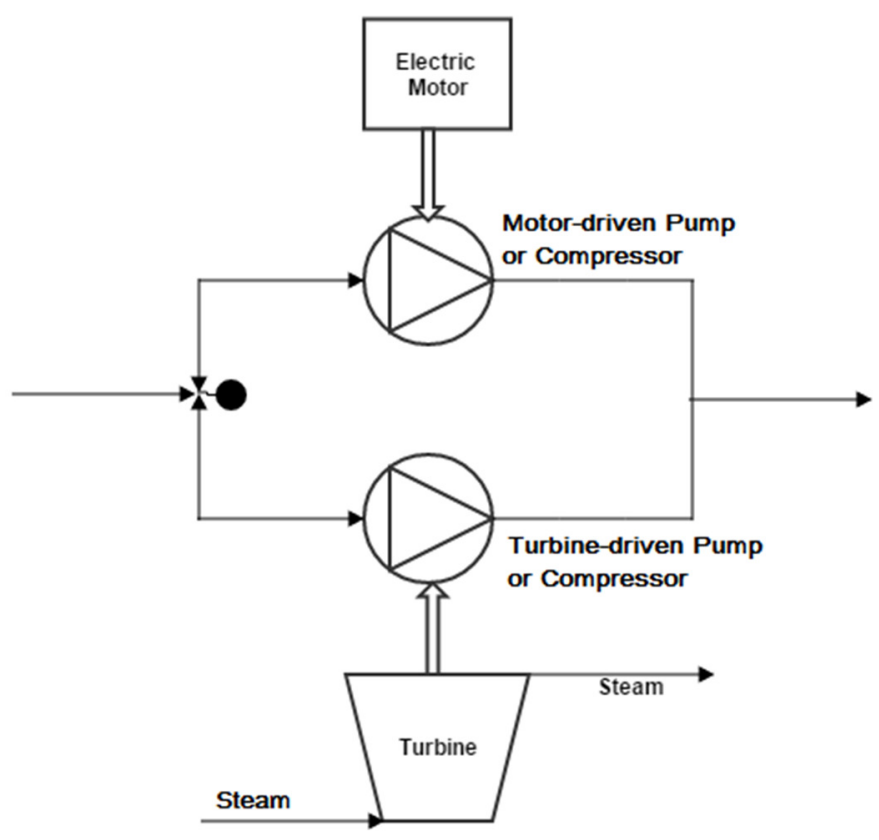

Figure 2. Switchable drive configuration for the options of steam turbine-driven or electrical motor-driven pumps or compressors 
Table 1. Operating modes for fuel and steam system

\begin{tabular}{|c|c|c|}
\hline $\begin{array}{l}\text { Characteristics of the two } \\
\text { general operating modes for } \\
\text { the fuel and steam system }\end{array}$ & $\begin{array}{l}\text { High production } \\
\text { of refinery gas }\end{array}$ & $\begin{array}{l}\text { Low production } \\
\text { of refinery gas }\end{array}$ \\
\hline Ambient temperature & High & Low \\
\hline $\begin{array}{l}\text { Condensation of products/ } \\
\text { Production of refinery gas }\end{array}$ & $\begin{array}{c}\text { Smaller amounts of valuable } \\
\text { products can be condensed, } \\
\text { and more refinery gas is } \\
\text { obtained }\end{array}$ & $\begin{array}{l}\text { Larger amounts valuable } \\
\text { products can be condensed, } \\
\text { and less refinery gas is } \\
\text { obtained }\end{array}$ \\
\hline Waste-heat-recovery boilers & Typically off & On \\
\hline Switchable machines & Mainly steam turbine driven & $\begin{array}{l}\text { Trade-off between cost of } \\
\text { LNG for the production of } \\
\text { steam for turbine drive and } \\
\text { electricity cost for electric } \\
\text { motor drive }\end{array}$ \\
\hline Steam boiler load & High & $\begin{array}{l}\text { Depends on trade-off for } \\
\text { switchable machines }\end{array}$ \\
\hline Steam venting & High & Low \\
\hline $\begin{array}{l}\text { Share of total plant } \\
\text { operating time }\end{array}$ & $\sim 25 \%$ & $\sim 75 \%$ \\
\hline
\end{tabular}

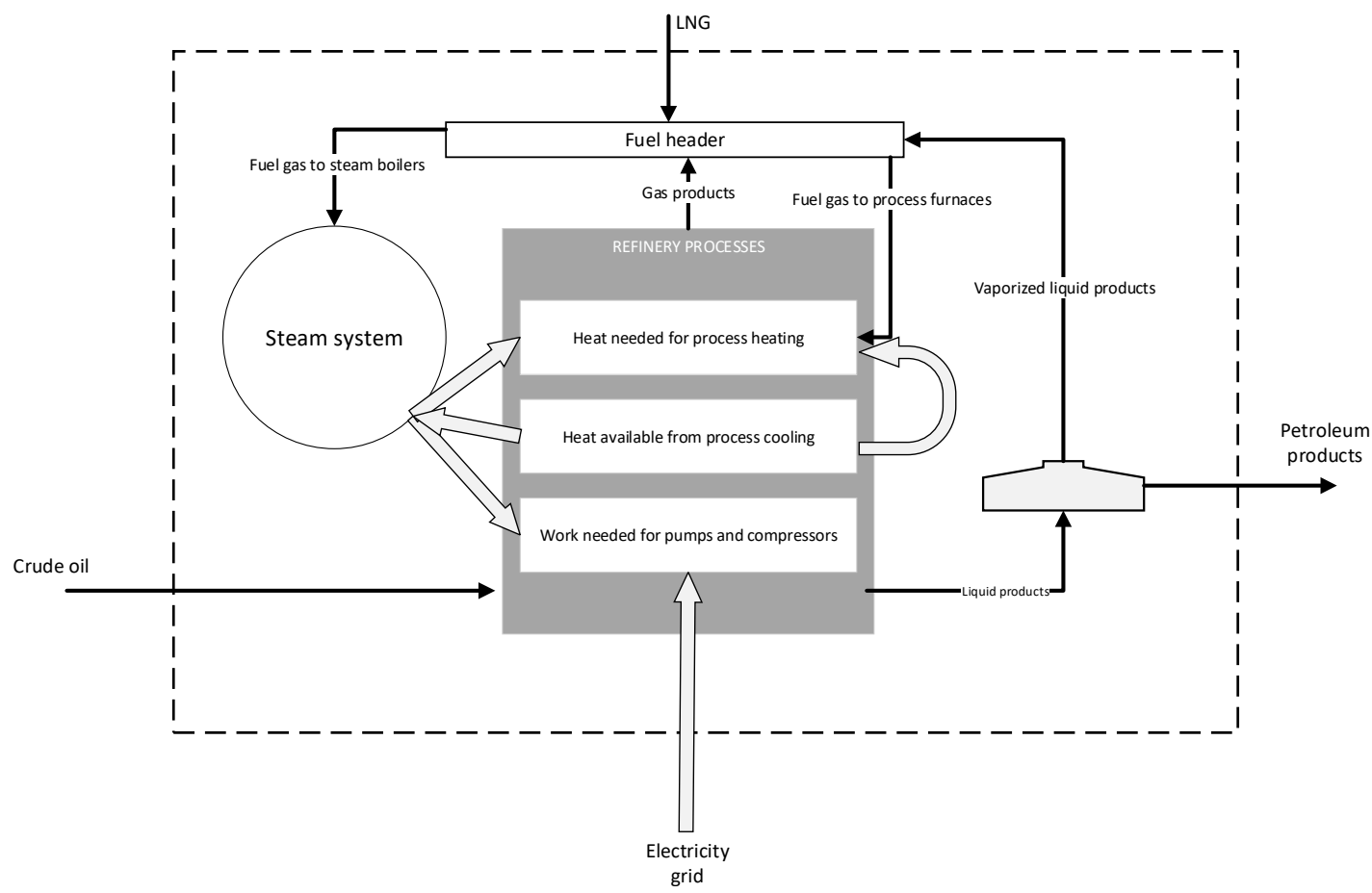

Figure 3. Overview of energy flows within the refinery

\section{METHODOLOGY}

The approach suggested for evaluation of the alternative HEN designs is to model the steam utility system of the refinery using a dedicated commercial software tool. The model is then used to simulate how the changes in steam consumption and production resulting from the process HEN retrofits affect the overall steam network balances under the different operating conditions. The scenarios used for the evaluation represent actual operating scenarios. 
Since there is currently no use of model-based operational optimization systems for the steam network at the refinery, decisions about how to change the operation are made manually by operators. In an attempt to mimic their behaviour, and thereby the most likely consequences of the retrofit, the developed steam system model is not used for optimization in the analysis of this paper. Instead, the changes in steam balances caused by the retrofit are followed by manual decisions to adjust the operation of turbines and boilers in the model. These decisions aim at reducing fuel use and maximizing power production while making sure that there is no deficit of steam of any pressure. Finally, the corresponding changes in fuel use and power production are extracted from the model.

\section{Heat Exchanger Network (HEN) retrofit}

The HEN retrofit proposals used in this study are based on results from an ongoing case study at an oil refinery. In the case study, several HEN retrofit proposals have been developed to investigate operability issues related to Heat Integration.

Stream data has been based on a previous Total Site targeting study [27]. The design approach for the HEN retrofits has been focused on improvement of individual process units. A traditional grid representation has been used to visualize the HEN of the process. In relation to the Pinch Temperature of the individual process, Cross-Pinch heat exchanger matches have been identified, Cross-Pinch heat transfer has been removed or reduced, and the heat loads re-distributed.

For several of the process units the HEN retrofit designs resulted in modified steam production and consumption rates. Furthermore, for many of the process units, alternative designs with different implications for the steam system have been suggested and analyzed. For example, Retrofit proposal A described below, is one of two proposals with the same fuel savings in the furnace. Retrofit proposal A uses excess Low-Pressure (LP) steam and the other proposal (not included in this paper) uses lower-temperature excess process heat. For this paper, three retrofit projects with clear effects on steam consumption or production have been selected.

\section{Steam network model}

Based on measurements within the plant, energy and mass balances, assumptions regarding unmeasured variables, component datasheets and interviews with company employees, a complete model of the refinery steam network has been created. Mass and energy balances have been established for the entire steam network, including steam production units, steam headers, turbines, valves, and desuperheaters, as well as steam consumptions. The components and their connections in the network have been modelled in Aspen Utilities planner [28] with user interfaces connected to Excel spreadsheets. The boilers fuel consumption, the electric power used for the electric-driven pumps, the vented steam and the make-up water have been included in the model to allow for a systems analysis of modifications made to the steam balances. For a detailed description of the steam utility network model, see [29].

The main operating scenario used for the construction of the model was chosen in discussion with refinery staff, and represents a normal steam production rate, with stable flows through the valves and stable steam production in the main boilers and heat recovery steam generators. The model of the steam system has been validated against plant measurements from this main scenario, and three other operating scenarios, as described in Table 2.

Besides enabling a validation of the model in different operating conditions, the comparison of the model outputs with measurement data for these three scenarios has been useful for identifying possible equipment failures, such as broken flow meters or indicators for pump driver switches. 
Table 2. The three operating scenarios, for which plant measurement data is collected and used for simulation and validation

\begin{tabular}{cccc}
\hline Scenario & Month & $\begin{array}{c}\text { Steam production } \\
\text { at VHP level }\end{array}$ & Comment \\
\hline 1 & Sep. & Medium & Main scenario \\
2 & Apr. & Medium & - \\
3 & Jul. & Low & Maintenance for some units of the refinery \\
\hline
\end{tabular}

It should be noted that all scenarios analyzed represent situations with a refinery gas deficit, which is the case during approximately $75 \%$ of the year, see Table 1 . Due to the deficit of refinery gas, LNG is imported. Consequently, a retrofit leading to fuel gas savings will enable a reduction of the LNG imports. For the $25 \%$ of the year with a refinery gas surplus, no Heat Integration retrofit will result in fuel savings. The produced refinery gas needs to be combusted, no matter if the heat is used or not. For this case, increased steam consumption or decreased steam production is beneficial. This makes the steam surplus smaller and thereby reduces the water losses from steam venting.

\section{HEAT INTEGRATION RETROFIT PROPOSALS}

In this section, the retrofit proposals are presented, focusing on their direct effect on local steam headers and fuel balances.

\section{Retrofit proposal A}

This retrofit proposal includes the heating of two process streams entering a reactor. The process streams are heated by the reactor outlet before being mixed and are then finally heated by a process furnace. The current process flowsheet is shown in Figure 4. Hot streams are indicated by dotted lines and stream mixing is indicated by a rhomb.

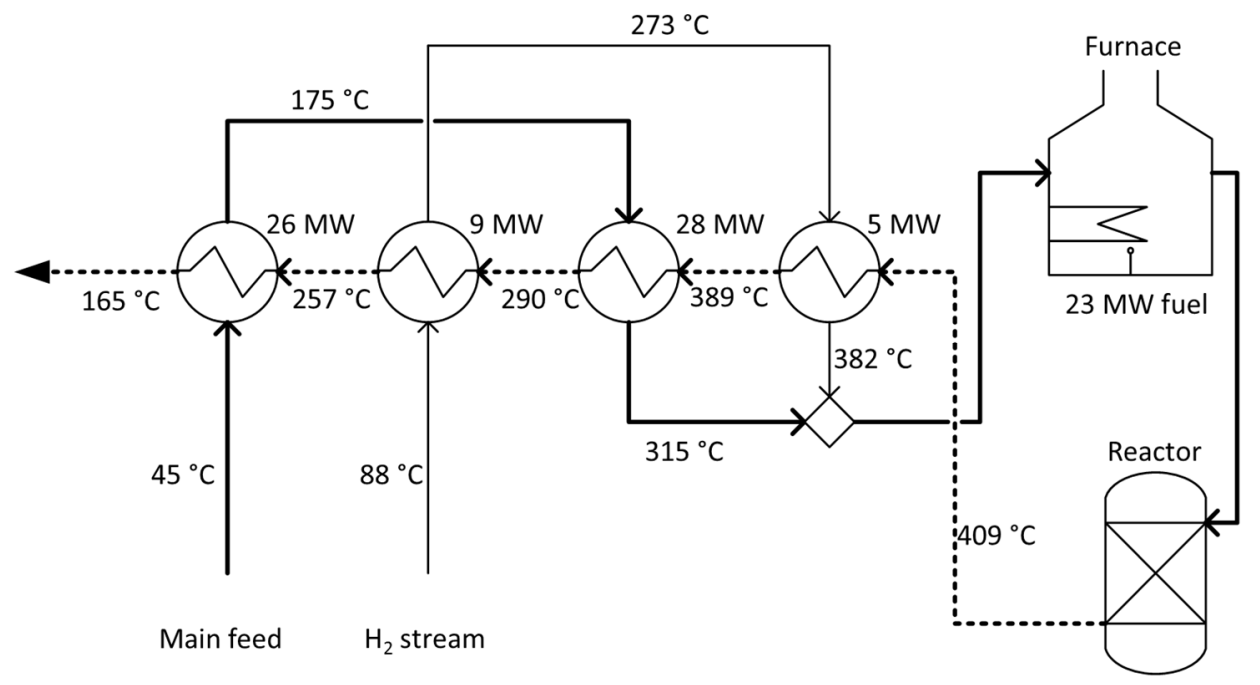

Figure 4. Current process scheme, before suggested changes to Retrofit proposal A

The suggested retrofit proposal is shown in Figure 5. The aim of the retrofit proposal is to reduce the amount of fuel gas consumed by the process furnace. To achieve the fuel savings, LP steam is used to pre-heat the main reactor feed stream, before entering existing heat exchanging equipment. In addition to the new heat exchanger, two of the existing heat exchangers need to be expanded, due to decreased temperature difference, to maintain the same load. In Figure 5, heat exchangers with increased area are indicated by a grey colour. All energy and equipment changes are shown in Table 3. LP steam 
consumption is increased by $9.7 \mathrm{MW}(17 \mathrm{t} / \mathrm{h})$, while the fuel consumption in the process furnace is decreased by $12.4 \mathrm{MW}$.

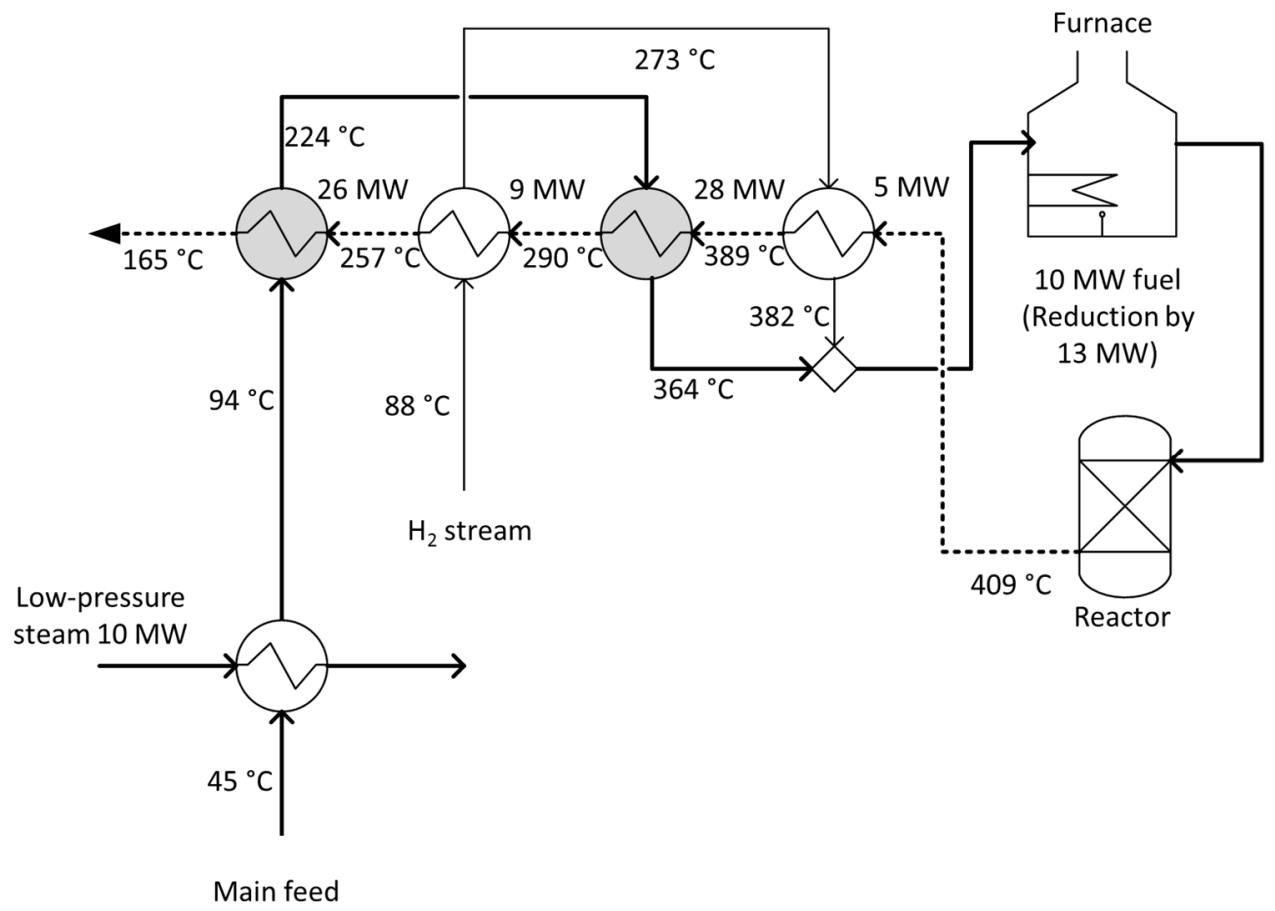

Figure 5. Retrofit proposal A

Table 3. Process equipment and energy consequences for Retrofit proposal A

\begin{tabular}{cccc}
\hline $\begin{array}{c}\text { Need for new heat } \\
\text { exchanger }\end{array}$ & $\begin{array}{c}\text { Need for increased } \\
\text { area in existing heat } \\
\text { exchangers }\end{array}$ & $\begin{array}{c}\text { LP steam consumption } \\
{[\mathrm{MW}]}\end{array}$ & $\begin{array}{c}\text { Fuel gas consumption } \\
\text { in process furnace } \\
{[\mathrm{MW}]}\end{array}$ \\
\hline 1 heat exchanger & 2 heat exchangers & $9.7(17 \mathrm{t} / \mathrm{h})$ & -12.4 \\
\hline
\end{tabular}

It should be added that this retrofit proposal is based on the assumption that there often is a surplus of LP steam vented to the atmosphere. The same fuel saving in the furnace could have been achieved by pre-heating the reactor feed with internal excess heat from the process unit, instead of by LP steam. However, using LP steam to pre-heat the reactor feed is likely to provide better operability compared to internal heat exchange because of the fewer interdependencies. When using LP steam to pre-heat the reactor feed, the effect on the overall fuel and steam balances from increasing the overall LP steam consumption is not obvious, hence, suggesting a need for modelling the entire steam system. In this paper, the assumption about availability of excess LP steam is assessed. Furthermore, a steam system model with data for three different operating scenarios is used to evaluate the steam system consequences when the excess of LP steam cannot cover the increased consumption.

\section{Retrofit proposal B}

For the process unit considered for Retrofit proposal B, generation of High-Pressure (HP) steam in process coolers serves as one of the cold utilities. In other words, in the process coolers a hot process stream is used to generate steam while the hot stream itself is cooled down. Whether this is a, thermodynamically, preferable solution in the perspective of the whole refinery depends on how - at which temperatures - the generated steam is used. A HEN retrofit decreasing the HP steam production, as well as 
the fuel gas consumption, is assessed to evaluate the Total Site fuel and electricity consequences.

Retrofit proposal B involves heating before a thermal separation unit, as shown in Figure 6. In the figure, hot process streams are indicated by dotted lines. The feed to the separation unit is first heated by internal heat exchange and then finally heated by a process furnace. The hot steam is currently cooled by a steam generation unit producing most of the HP steam at the refinery.
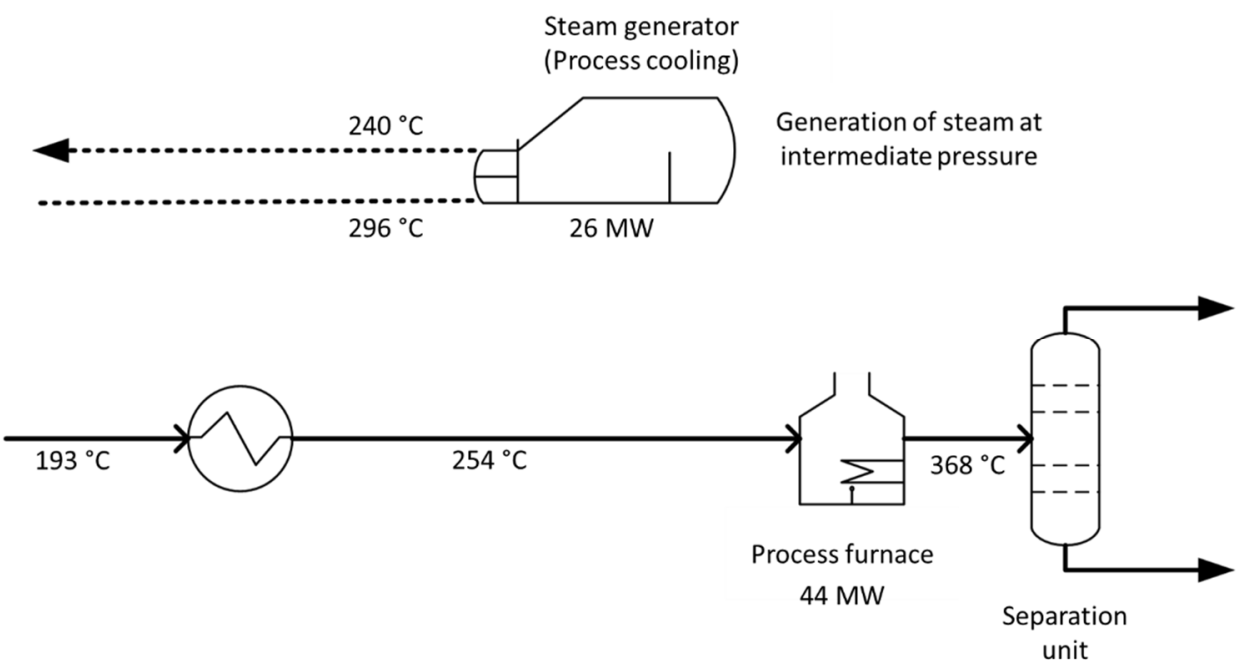

Figure 6. Process scheme before Retrofit proposal B

The retrofit proposal is designed to use some of the excess heat in the hot stream to pre-heat the inlet to the separation unit. This enables a reduced load of the process furnace, but also leads to a decreased production of HP steam. The retrofit proposal is shown in Figure 7.

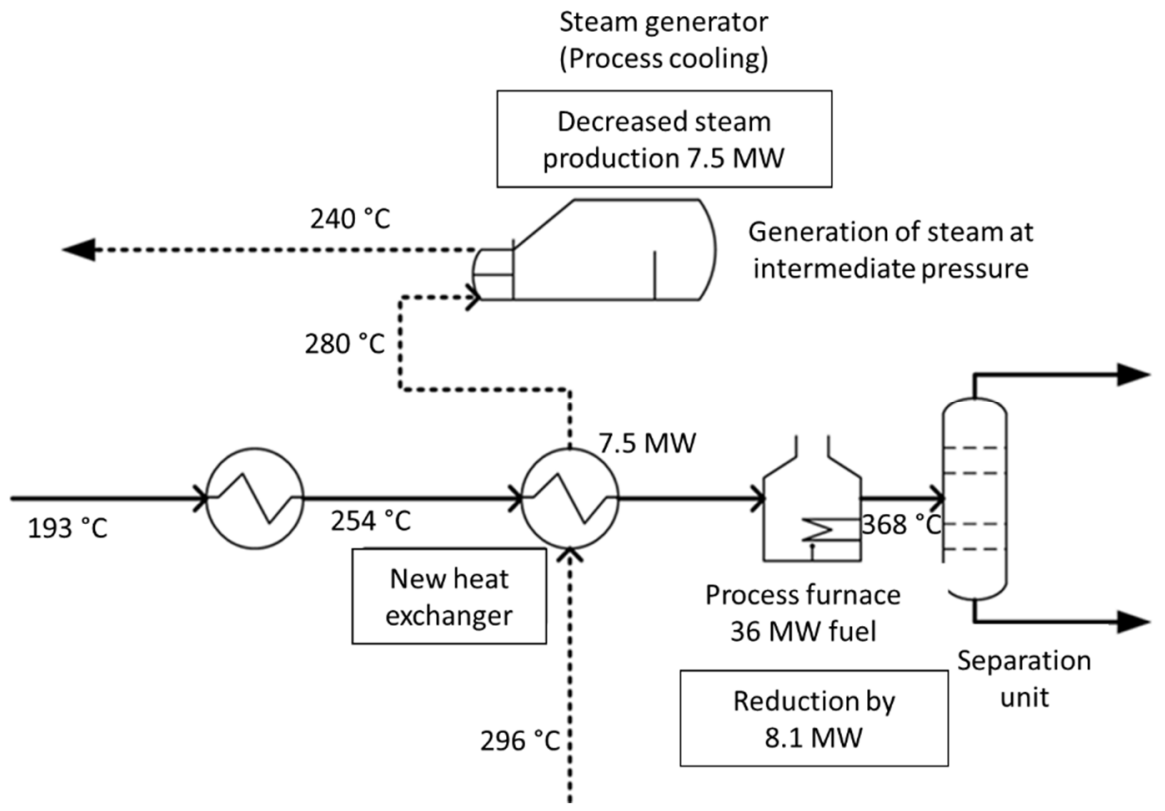

Figure 7. Retrofit proposal B

For this retrofit proposal, one new heat exchanger is required. As previously stated, both fuel gas consumption and HP steam production are decreased locally at the process unit. All changes are shown in Table 4. 
Table 4. Process equipment and energy consequences for Retrofit proposal B

\begin{tabular}{ccc}
\hline Need for new heat exchanger & HP steam production $[\mathrm{MW}]$ & $\begin{array}{c}\text { Fuel gas consumption in } \\
\text { process furnace }[\mathrm{MW}]\end{array}$ \\
\hline 1 heat exchanger & $-7.5(14 \mathrm{t} / \mathrm{h})$ & -8.1 \\
\hline
\end{tabular}

It is not obvious how the decreased production of HP steam will affect the fuel and steam balances for the Total Site; it depends on the steam balances for the different steam headers.

\section{Retrofit proposal C}

Retrofit $\mathrm{C}$ involves the heat needed for a distillation tower reboiler, which is currently provided by LP steam. In Figure 8, parts of the process flowsheet before the retrofit is shown. In Figure 8, a hot stream is shown by dotted lines and it can be seen that this hot stream is currently cooled by air fans. The retrofit proposal, shown in Figure 9, includes a replacement of the LP steam heating by internal heat exchange.
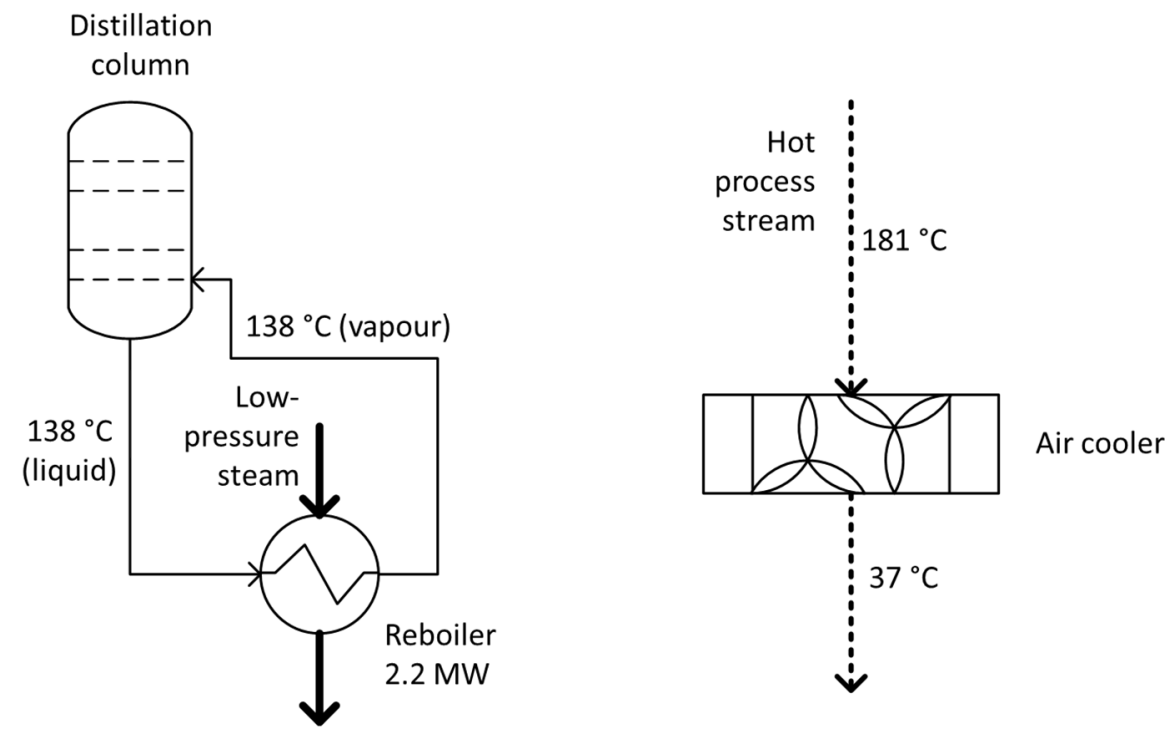

Figure 8. Process scheme before Retrofit proposal C

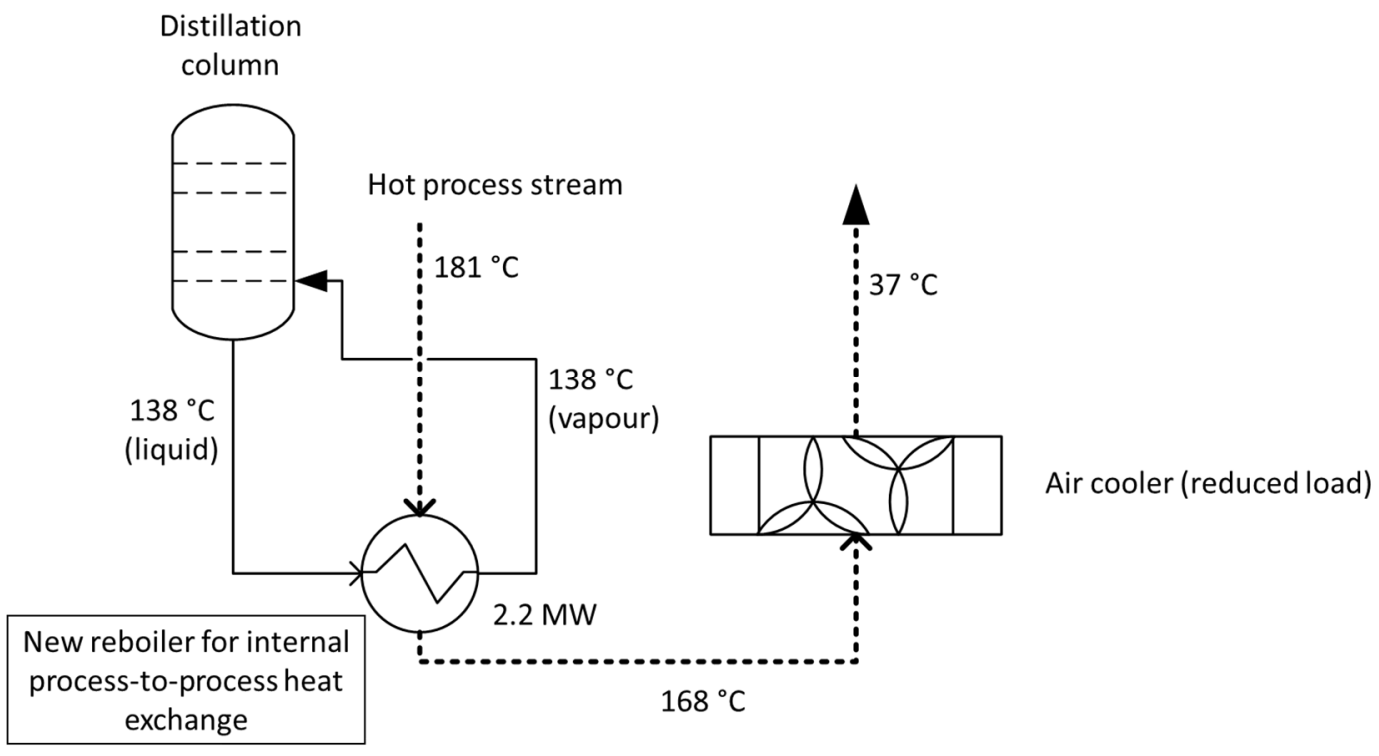

Figure 9. Retrofit proposal C 
The retrofit will decrease the LP steam consumption by $2.2 \mathrm{MW}$. It will also require new heat transfer area since the internal heat exchange will lead to a significantly lower heat transfer coefficient than when condensing LP steam was used in the reboiler. The potential reduction in electricity used for the cooling fans is neglected. All changes are summarized in Table 5.

Table 5. Process equipment and energy consequences for Retrofit proposal C

\begin{tabular}{cc}
\hline $\begin{array}{c}\text { Need for increased reboiler heat transfer area, } \\
\text { possibly with new equipment }\end{array}$ & LP steam consumption \\
\hline 1 heat exchanger & $-2.2(4 \mathrm{t} / \mathrm{h})$ \\
\hline
\end{tabular}

\section{STEAM UTILITY SYSTEM CONSEQUENCES OF HEAT EXCHANGER NETWORK RETROFITS}

In this section, the results from the steam network model will be presented and analysed for retrofit proposals A, B and C. For each retrofit, the consequences to the steam network are evaluated for the three scenarios presented in Table 2.

\section{Retrofit proposal A}

As described above, this retrofit proposal involves increased consumption of LP steam. Depending on the steam balance at the LP header, this will affect the steam balances at other headers and the fuel gas consumption in the steam boilers.

For all scenarios analysed, LP steam is currently vented to the atmosphere. The total venting of LP steam in each scenario is shown in Table 6.

Table 6. LP steam venting for all scenarios

\begin{tabular}{cc}
\hline Scenario & LP steam venting $[\mathrm{t} / \mathrm{h}]$ \\
\hline 1 & 16.2 \\
2 & 23.9 \\
3 & 4.9 \\
\hline
\end{tabular}

The HEN retrofit analysed here involves an increase in LP steam consumption of $17 \mathrm{t} / \mathrm{h}$. Although all scenarios have an excess of LP steam, the surplus varies and is not always sufficient to cover the increased consumption. In the scenarios with a venting of LP steam lower than $17 \mathrm{t} / \mathrm{h}$, the amount of steam delivered to the LP header need to be increased to compensate for the increased steam consumption.

The only reasonably feasible way to accomplish this is to compensate for the LP steam deficit through increased VHP steam production in the steam boilers. If the VHP steam production is significantly increased, the VHP steam can be used in VHP $\rightarrow$ LP steam turbines, thereby decreasing the imported electricity to the plant. From a theoretical modelling perspective the amount of steam delivered to the LP header can also be increased by turning off steam turbine drives for switchable equipment, and instead let down steam from higher pressure headers through let-down valves. This would, however, require a significant number of turbines to be turned off, which consequently would lead to a significant increase in the demand for electricity to the site and a substantial reduction in the overall efficiency of the steam system. Results for implementing Retrofit A are shown for all scenarios in Table 7. The largest change to the steam utility system is necessary in Scenario 3, for which steam venting and VHP steam production before the retrofit is low.

As seen in Table 7, the retrofit proposal gives fuel savings for all scenarios. However, the third scenario has quite low savings. Instead, the main saving in Scenario 3 is in 
electricity due to the increased use of VHP $\rightarrow$ LP steam turbines for switchable-drive pump and compressors. The other scenarios give large savings in fuel gas and the increased consumption of LP steam from the retrofit proposal does not give a large overall increased consumption of fuel gas in the steam boilers. The retrofit proposal could therefore be assumed to achieve most of the estimated fuel gas savings for the $75 \%$ of the year when the refinery has a deficit of refinery gas.

Table 7. Resulting changes to fuel and electricity balances for Retrofit proposal A

\begin{tabular}{ccccc}
\hline Scenario & $\begin{array}{c}\text { Changed fuel gas } \\
\text { consumption in } \\
\text { steam boilers [MW] }\end{array}$ & $\begin{array}{c}\text { Changes fuel gas } \\
\text { consumption in } \\
\text { process furnace } \\
{[\mathrm{MW}]}\end{array}$ & $\begin{array}{c}\text { Total Site changes in } \\
\text { LNG consumption } \\
{[\mathrm{MW}]}\end{array}$ & $\begin{array}{c}\text { Total Site changes } \\
\text { in electricity } \\
\text { consumption [MW] }\end{array}$ \\
\hline 1 & 0.7 & -12.4 & -11.7 & - \\
2 & - & -12.4 & -12.4 & - \\
3 & 10.6 & -12.4 & -1.8 & -0.8 \\
\hline
\end{tabular}

It is possible, and for some scenarios even likely, that the steam venting could be reduced directly by changing the steam system operation, typically, by reducing the let-down of steam through valves and turbines. If the steam venting was avoided by operational optimization, implementation of Retrofit A would give similar results in all scenarios as those for Scenario 3, that is, the steam production in the boilers would have to be increased to cover the increased LP steam demand. This in turn would enable increased generation of work in the steam turbines connected to the VHP header. Consequently, the overall result of the retrofit would be that fuel use is moved from the process furnace to the steam boilers, which, depending on the availability of turbine capacity, can give a potential increase in cogeneration.

In the analysis, it is assumed that the process will be operated according to the retrofit design proposal, that is, with an increased use of LP steam of $17 \mathrm{t} / \mathrm{h}$ and a reduced load of the furnace corresponding to a reduction of $12.4 \mathrm{MW}$ of fuel gas. If the excess of LP steam is not enough to cover the increased demand, additional steam is assumed to be generated in the steam boilers. Another realistic alternative would be that, in each operating scenario, only the available LP steam excess is used, with a resulting lower fuel gas saving in the furnace. Consequently, there would be no savings in electricity consumption in those cases, but on the other hand, the steam system will be less affected.

\section{Retrofit proposal B}

Retrofit proposal B includes changes to the HP steam production. By increased internal heat exchange, the HP steam production is reduced by $14 \mathrm{t} / \mathrm{h}$, see Table 4 . The HEN retrofit has a direct effect not only the HP steam header, but also on the MP and LP header. If the steam production to the HP header is decreased, less steam will go through steam turbines and let-down valves to the MP and LP steam headers, thereby affecting the balances on these steam headers as well.

As shown in Table 8, HP steam is currently used in steam turbines and let down through valves in all scenarios analyzed.

Table 8. Steam from HP, MP and LP headers to turbines, let-down valves and steam vents

\begin{tabular}{cccccc}
\hline \multirow{2}{*}{ Scenario } & $\begin{array}{c}\text { HP to valves } \\
{[\mathrm{t} / \mathrm{h}]}\end{array}$ & $\begin{array}{c}\text { HP to turbines } \\
{[\mathrm{t} / \mathrm{h}]}\end{array}$ & $\begin{array}{c}\text { MP to valves } \\
{[\mathrm{t} / \mathrm{h}]}\end{array}$ & $\begin{array}{c}\text { MP to turbines } \\
{[\mathrm{t} / \mathrm{h}]}\end{array}$ & $\begin{array}{c}\text { LP venting } \\
{[\mathrm{t} / \mathrm{h}]}\end{array}$ \\
\hline 1 & 19.9 & 19.8 & 24.8 & 68.6 & 16.2 \\
2 & 7.4 & 31.5 & 18.8 & 68.6 & 23.9 \\
3 & 9.5 & 24.5 & 5.2 & 46.9 & 4.9 \\
\hline \multicolumn{7}{c}{572}
\end{tabular}


For Scenario 1, the steam flow to let-down valves from the HP header is larger than the $14 \mathrm{t} / \mathrm{h}$ of steam production that will be lost by Retrofit proposal B. Moreover, the surplus of steam at the MP and LP header is high enough to compensate for the decreased steam rate through the let-down valves. Hence, the only change in the steam utility system is that less steam goes through let-down valves and the LP steam venting is decreased. Consequently, for Scenario 1, the retrofit gives a fuel gas saving in the process furnace and does not affect the fuel consumption in steam boilers or electricity consumption for pumps or compressors. Thereby, the retrofit leads to a Total Site reduction in LNG consumption for this scenario. The energy balances for the process unit and for the Total Site are shown in Table 9.

For Scenarios 2 and 3, the steam flow to let-down valves from the HP level before the retrofit is not enough to cover the decrease in steam production caused by the HEN retrofit. Consequently, the retrofit will make it necessary to either let down more steam from the VHP header to the HP header, or to decrease the use of HP steam for turbine-driven machines.

For Scenario 2, there is a steam surplus at the MP and LP header after implementation of Retrofit B. Hence, turning off turbines from the HP to the MP or LP headers will likely not have large consequences for the steam balances of the MP and LP headers. For Scenario 2, there are two alternatives for turbines to turn off in order to reduce the use of HP steam. The choice is between one HP $\rightarrow$ MP turbine and one HP $\rightarrow$ LP turbine. The $\mathrm{HP} \rightarrow \mathrm{MP}$ turbine has a much larger steam flow than the HP $\rightarrow$ LP turbine, but a lower enthalpy drop, and the optimum decision is therefore not obvious. In Table 9, Scenario 2-1 represents the alternative of turning off the HP $\rightarrow$ LP turbine and 2-2 is to turn off the $\mathrm{HP} \rightarrow \mathrm{MP}$ turbine.

As seen in Table 9, the increase in electricity consumption, resulting from replacing steam turbine-driven machines by electric motor-driven machines, is smaller for Alternative 2-2 than for Alternative 2-1. However, even though both options only give a small increase in electricity consumption, none of them is the best choice. For this scenario, it is better to increase let-down steam from the VHP steam header, displayed as Scenario 2-3 in Table 9. This is because there is more steam available at the VHP header in this Scenario 2 than what is currently used for turbines, that is, VHP steam is in this scenario let down through valves to the MP and further to the LP headers, but could instead be let down to the HP header.

Table 9. Resulting changes to fuel and electricity balances for Retrofit proposal B

\begin{tabular}{ccccc}
\hline Scenario & $\begin{array}{c}\text { Changed fuel gas } \\
\text { consumption in } \\
\text { steam boilers } \\
{[\mathrm{MW}]}\end{array}$ & $\begin{array}{c}\text { Changes fuel gas } \\
\text { consumption in } \\
\text { process furnace } \\
{[\mathrm{MW}]}\end{array}$ & $\begin{array}{c}\text { Total Site changes } \\
\text { in LNG } \\
\text { consumption } \\
{[\mathrm{MW}}\end{array}$ & $\begin{array}{c}\text { Total Site changes } \\
\text { in electricity } \\
\text { consumption } \\
{[\mathrm{MW}]}\end{array}$ \\
\hline 1 & - & -8.1 & -8.1 & - \\
$2-1$ & - & -8.1 & -8.1 & 0.3 \\
$2-2$ & - & -8.1 & -8.1 & 0.2 \\
$2-3$ & - & -8.1 & -8.1 & - \\
$3-1$ & 9.3 & -8.1 & 1.3 & -0.2 \\
$3-2$ & 9.0 & -8.1 & 1.0 & - \\
\hline
\end{tabular}

It should be mentioned, again, that the operation of the steam system before the retrofit was not mathematically optimized. It is likely that the let-down of VHP steam in Scenario 2 would not be seen in the results from a model-based optimization of the operational scenario. For Scenario 2, fuel gas savings could easily have been achieved directly in the steam boilers, if let-down and steam venting was reduced. The surplus of steam at MP and LP headers would thereby be reduced. Consequently, if this was done 
before Retrofit B was implemented, the retrofit would lead to a requirement to increase the VHP steam production in the steam boilers to compensate for the lost HP steam production. This could lead to similar consequences of Retrofit B in Scenario 2 as those described for Scenario 3 below.

For Scenario 3 the steam flows through let-down valves are low between all steam headers. Therefore, the decreased steam production caused by Retrofit B has large consequences for the steam utility system. Implementation of Retrofit B in Scenario 3 requires compensation of the lost steam production at the HP header as well as at the MP and LP header. For the VHP header, there is only a small surplus of steam for Scenario 3. In the same way as for Scenario 2, steam turbines connected to the HP header can be turned off. However, while this compensates for lost steam production at the HP header, it will only move the problem to the MP and LP header. Consequently, the VHP steam production in the steam boilers needs to be increased instead. The VHP steam can be used in turbines from the VHP pressure header to both MP and LP pressures. This alternative is shown as Scenario 3-1 in Table 9. Because of the increased steam flow from the VHP header to turbines that drive switchable equipment, the electricity consumption is decreased even though some turbines were switched off from the HP pressure level. Nevertheless, the increased steam production in the steam boilers leads to an increased LNG consumption for the Total Site, which makes the retrofit proposal non-profitable for Scenario 3-1. The second alternative for Scenario 3 is to increase the VHP steam production in the boilers and increase let-down steam to the HP level until no steam deficit at any header remains. The steam turbine operation is not changed; hence, the electricity consumption is not changed. For this Scenario 3-2, the Total Site fuel consumption increases which leads to an increase in the purchased LNG to the refinery, making this alternative economically unfeasible as well.

The results show that the HEN retrofit proposal gives large reductions in purchased LNG to the refinery for most operating conditions. Scenario 3 is a special case for which parts of the refinery are shut down due to maintenance, and does therefore not represent everyday operation. However, Scenario 3 is probably closer to an optimized operation with only small steam flows through let-down valves and to vent. Therefore, the analysis for Scenario 3 is still important and shows that the energy saving potential and expected profitability for Retrofit B are questionable for an optimized operation of the steam utility system.

\section{Retrofit proposal C}

For Retrofit $\mathrm{C}$, there are no changes to the overall energy balances of the refinery, except a potential small reduction in electricity use for the cooling fans. Since there is an excess of LP steam for all scenarios, the only consequence of the LP steam saving achieved by this retrofit is an increased LP steam venting and increased water losses. Retrofit $\mathrm{C}$ is thereby not profitable for the investigated scenarios. The results on the steam system might have other effects if optimized operation (with minimized steam venting) is considered.

\section{DISCUSSION}

The evaluation approach suggested in this paper is based on model simulations resulting from manual decisions on how to adjust the operation of boilers and turbines in effect of a proposed change. The evaluation is thereby based on a comparison of two mathematically, non-optimized operating scenarios. Consequently, further savings could theoretically be achieved by optimizing the operation of the steam network both for the current and for the retrofitted process. The model of the steam network could be used for that kind of optimization if prices for fuel and electricity are provided. It is, however, 
important to remember that the operator's decisions are based on more information than currently included in the model, for example, knowledge about ongoing maintenance work, planned changes in operation, duration of operational transitions, etc. In other words, the real steam network need to be operated to ensure some flexibility for future unexpected, and planned, changes and variations in operating conditions, which are not considered in the mathematical, steady-state optimization model.

It is clear that economic factors like investment cost and fuel and electricity cost savings will ultimately be the deciding factors for whether an energy-efficiency investment will be implemented. The analysis presented in this paper gives the basic input needed to evaluate the effect of the heat saving measures on fuel and electricity costs if combined with energy price information relevant for the studied refinery. Investment costs for the suggested heat-saving measures can be estimated using cost functions for heat exchangers, or with more detail based on vendor quotes. However, the details of the cost estimations and energy price statistics were not made available for publication in this research project. Economic considerations are included in the Pinch-based design methods through the choice of the minimum temperature difference for heat exchange that reflects a trade-off between investment costs for heat exchanger area and operating costs for energy utility. Costs for new heat exchangers and reduced costs for energy utility are generally straightforward to estimate and these could then be used for estimating the expected profitability of a heat integration project, for example, by simple Payback Periods (PR), Internal Rate of Returns (IRR) or Net Present Values (NPV).

Experience has shown that other factors also greatly influence the decision on investment. These could be concerns about how the operability of the process is affected, for example, regarding reliability or controllability. These could also be practical considerations regarding the implementation, for example, whether there is sufficient space available in the plant. For some heat-saving proposals, the operability and implementation issues will make the project completely unfeasible. For others, consideration to the requirements on operability and practical implementation will affect the expected cash flows of the Heat Integration project. Typically, operability issues could lead to lower heat savings than expected from the base-line analysis, thereby leading to lower operational cost savings, or they could lead to additional investments in, for example, more compact heat exchangers, added measurements and/or manipulators for control, or back-up systems to overcome potential problems.

However, Heat Integration projects can potentially also enable improvements in quality and/or production rates for the main products in the plant. If that is the case, the economics of the projects could be significantly strengthened compared to a simple heat saving measure. An excellent example of this kind of Non-Energy Benefit of energy efficiency projects has been presented by Aseeri et al. [30]. Future work is needed to develop easily-applied methods within the Heat Integration field that consider operability aspects and other practical design constraints in combination with economic evaluations.

\section{CONCLUSIONS}

This paper presents examples from an industrial case study, in which Heat Integration retrofits are evaluated in terms of their consequences for the operation of the steam utility network. The analysis of Heat Integration projects, which involve modifications to the steam consumption or production, shows the importance of expanding the system boundaries to include the entire steam system to enable evaluation of overall fuel savings and associated changes in electricity imports. The paper also shows that the overall energy savings vary between different operating scenarios, and that operational data for several scenarios, and their expected share of the yearly operating time, are necessary to 
evaluate the energy consequences of HEN retrofits including the steam utility network. Among other things, the selected examples show that availability of steam excess at certain steam headers during a large part of the year could be used to decrease the fuel used in process furnaces without necessarily increasing the fuel consumption in steam boilers.

In this paper, the analysis is based on analysing changes for a few discrete operating scenarios, that represent real operating conditions and decisions that have occurred in the studied plant. For these scenarios, savings could possibly be achieved also by a direct optimization of the operation of the steam utility system. The steam network model developed for this work can be used also for this kind of optimization, given that price data for fuels and electricity are provided.

\section{REFERENCES}

1. Dunn, R. F. and El-Halwagi, M. M., Process Integration Technology Review: Background and Applications in the Chemical Process Industry, Journal of Chemical Technology and Biotechnology, Vol. 78, No. 9, pp 1011-1021, 2003, https://doi.org/10.1002/jctb.738

2. Klemeš, J. J. and Kravanja, Z., Forty Years of Heat Integration: Pinch Analysis (PA) and Mathematical Programming (MP), Current Opinion in Chemical Engineering, Vol. 2, No. 4, pp 461-474, 2013, https://doi.org/10.1016/j.coche.2013.10.003

3. Nemet, A., Klemeš, J. J., Varbanov, P. S. and Mantelli, V., Heat Integration Retrofit Analysis - An Oil Refinery Case Study by Retrofit Tracing Grid Diagram, Frontiers of Chemical Science and Engineering, Vol. 9, No. 2, pp 163-182, 2015, https://doi.org/10.1007/s11705-015-1520-8

4. Yong, J. Y., Varbanov, P. S. and Klemeš, J. J., Heat Exchanger Network Retrofit supported by Extended Grid Diagram and Heat Path Development, Applied Thermal Engineering, Vol. 89, pp 1033-1045, 2015, https://doi.org/10.1016/j.applthermaleng.2015.04.025

5. Bonhivers, J.-C., Srinivasan, B. and Stuart, P. R., New Analysis Method to Reduce the Industrial Energy Requirements by Heat-exchanger Network Retrofit: Part 1 Concepts, Applied Thermal Engineering, Article in Press, 2014, https://doi.org/10.1016/j.applthermaleng.2014.04.078

6. Kamel, D. A., Gadalla, M. A., Abdelaziz, O. Y., Labib, M. A. and Ashour, F. H., Temperature Driving Force (TDF) Curves for Heat Exchanger Network Retrofit A Case Study and Implications, Energy, Vol. 123, pp 283-295, 2017, https://doi.org/10.1016/j.energy.2017.02.013

7. Chew, K. H., Klemeš, J. J., Alwi, S. R. W. and Abdul Manan, Z., Industrial Implementation Issues of Total Site Heat Integration, Applied Thermal Engineering, Vol. 61, No. 1, pp 17-25, 2013, https://doi.org/10.1016/j.applthermaleng.2013.03.014

8. Hackl, R. and Harvey, S., From Heat Integration Targets Toward Implementation A TSA (Total Site Analysis)-based Design Approach for Heat Recovery Systems in Industrial Clusters, Energy, Vol. 90, Part 1, pp 1-10, 2014, https://doi.org/10.1016/j.energy.2015.05.135

9. Liew, P. Y., Wan Alwi, S. R., Varbanov, P. S., Manan, Z. A. and Klemeš, J. J., Centralised Utility System Planning for a Total Site Heat Integration Network, Computers and Chemical Engineering, Vol. 57, pp 104-111, 2013, https://doi.org/10.1016/j.compchemeng.2013.02.007

10. Liew, P. Y., Wan Alwi, S. R. and Klemeš, J. J., Total Site Heat Integration Targeting Algorithm Incorporating Plant Layout Issues, Computer Aided Chemical Engineering, $\quad$ Vol. 33, pp 1801-1806, 2014, https://doi.org/10.1016/B978-0-444-63455-9.50135-5

11. Chew, K. H., Klemeš, J. J., Wan Alwi, S. R. and Manan, Z. A., Process Modification of Total Site Heat Integration Profile for Capital Cost Reduction, Applied Thermal 


$\begin{array}{llllll}\text { Engineering, } & \text { Vol. } & \text { 89, } & \text { pp }\end{array}$
https://doi.org/10.1016/j.applthermaleng.2015.02.064

12. Liew, P. Y., Lim, J. S., Wan Alwi, S. R., Abdul Manan, Z., Varbanov, P. S. and Klemeš, J. J., A Retrofit Framework for Total Site Heat Recovery Systems, Applied Energy, Vol. 135, pp 778-790, 2014, https://doi.org/10.1016/j.apenergy.2014.03.090

13. Gharaie, M., Panjeshahi, M. H., Kim, J.-K., Jobson, M. and Smith, R., Retrofit Strategy for the Site-wide Mitigation of $\mathrm{CO}_{2}$ Emissions in the Process Industries, Chemical Engineering Research and Design, Vol. 94, pp 213-241, 2015, https://doi.org/10.1016/j.cherd.2014.08.007

14. Čuček, L. and Kravanja, Z., Retrofit of Total Site Heat Exchanger Networks by Mathematical Programming Approach (Martín, M., ed.), Alternative Energy Sources and Technologies, Springer International Publishing, Switzerland, Ch. 11, pp 297-340, 2016.

15. Mehdizadeh Fard, M., Pourfayaz, F., Kasaeian, A. B. and Mehrpooya, M., A Practical Approach to Heat Exchanger Network Design in a Complex Natural Gas Refinery, Journal of Natural Gas Science and Engineering, Vol. 40, pp 141-158, 2017, https://doi.org/10.1016/j.jngse.2017.02.001

16. Varbanov, P., Perry, S., Makwana, Y., Zhu, X. X. and Smith, R., Top-level Analysis of Site Utility Systems, Chemical Engineering Research \& Design, Vol. 82, No. A6, pp 784-795, 2004, https://doi.org/10.1205/026387604774196064

17. Currie, J. and Wilson, D. I., Rigorously Modelling Steam Utility Systems for Mixed Integer Optimization, Proceedings of IEEE Conference on Power \& Energy - IPEC, Ho Chi Minh City, Vietnam, pp 526-531, 12-14 December, 2012, https://doi.org/10.1109/asscc.2012.6523323

18. Aguilar, O., Smith, R., Perry, S. and Kim, J. K., Optimising the Design and Operation of Industrial Utility Plants Subject to Variable Demands and Prices, Computer Aided Chemical Engineering, Vol. 20, pp 907-912, 2005, https://doi.org/10.1016/S1570-7946(05)80273-1

19. Velasco-Garcia, P., Varbanov, P., Arellano-Garcia, H. and Wozny, G., Utility Systems Operation: Optimisation-based Decision making, Applied Thermal Engineering, Vol. 31, No. 16, pp 3196-3205, 2011, https://doi.org/10.1016/j.applthermaleng.2011.05.046

20. Sun, L., Doyle, S. and Smith, R., Understanding Steam Costs for Energy Conservation Projects, Applied Energy, Vol. 161, pp 647-655, 2016, https://doi.org/10.1016/j.apenergy.2015.09.046

21. Svensson, E., Flexibility to Seasonal demand Variations in Pulp Mill Steam Production: The Effect of Steam Savings leading to Off-design Heat Loads, Applied Thermal Engineering, Vol. 70, No. 2, pp 1180-1188, 2014, https://doi.org/10.1016/j.applthermaleng.2014.04.059

22. Kim, S. H., Yoon, S. G., Chae, S. H. and Park, S., Economic and Environmental Optimization of a Multi-site Utility Network for an Industrial Complex, Journal of Environmental Management, Vol. 91, No. 3, pp 690-705, 2010, https://doi.org/10.1016/j.jenvman.2009.09.033

23. Aguilar, O., Kim, J. K., Perry, S. and Smith, R., Availability and Reliability Considerations in the Design and Optimisation of Flexible Utility Systems, Chemical Engineering Science, Vol. 63, No. 14, pp 3569-3584, 2008, https://doi.org/10.1016/j.ces.2008.04.010

24. Varbanov, P. S., Doyle, S. and Smith, R., Modelling and Optimization of Utility Systems, Chemical Engineering Research \& Design, Vol. 82, No. A5, pp 561-578, 2004, https://doi.org/10.1205/026387604323142603

25. Micheletto, S. R., Carvalho, M. C. A. and Pinto, J. M., Operational Optimization of the Utility System of an Oil Refinery, Computers \& Chemical Engineering, Vol. 32, No. 1-2, pp 170-185, 2008, https://doi.org/10.1016/j.compchemeng.2007.05.013 
26. Ruiz, D. and Ruiz, C. A., Industrial Experience in the Deployment of Real Time Online Energy Management Systems, Computer Aided Chemical Engineering, Vol. 27, pp 1455-1460, 2009, https://doi.org/10.1016/S1570-7946(09)70633-9

27. Andersson, E., Franck, P., Åsblad, A. and Berntsson, T., Pinch Analysis at Preem LYR, Report, Chalmers University of Technology, Göteborg, Sweden, 2013.

28. AspenTech, Aspen One Engineering Suite v 8.8 Software, 2015.

29. Subiaco, R., Modelling, Simulation and Optimization Perspectives of an Industrial Steam Network - Case Study at a Major Oil Refinery on the West Coast of Sweden, Internship Report, Chalmers University of Technology, Göteborg, Sweden, 2016.

30. Aseeri, A. S., Amin, M. S. and Ibrahim, M. S., Debottlenecking through Heat Integration (Case Study: Crude Distillation Unit), Society of Petroleum Engineers ADIPEC: $14^{\text {th }}$ Abu Dhabi International Petroleum Exhibition and Conferense, Vol. 1, pp 111-114, Abu Dhabi, 2010. 